Krystyna Mitręga-Niestrój*

\title{
KOREA POŁUDNIOWA - DOŚWIADCZENIA DWÓCH KRYZYSÓW FINANSOWYCH
}

\section{Wprowadzenie}

Korea Południowa w okresie zaledwie nieco ponad 10 lat doświadczyła dwóch kryzysów finansowych, które nie tylko miały negatywne następstwa w krajowym systemie finansowym, ale również oddziałały destrukcyjnie na gospodarkę. Kryzys finansowy w 1997 r. pojawił się po ponaddziesięcioletnim okresie dynamicznego wzrostu gospodarczego. W wypadku kryzysu lat 2008-2009, który był przede wszystkim konsekwencją amerykańskiego kryzysu subprime, zaburzenia nastąpiły po dekadzie intensywnego procesu restrukturyzacji koreańskiej gospodarki i sektora finansowego, w następstwie kryzysu azjatyckiego.

Celem artykułu jest $\mathrm{z}$ jednej strony ukazanie warunków, które doprowadziły do kryzysu finansowego w 1997 r., a z drugiej próba odpowiedzi na pytanie, czy podobne czynniki wystąpiły w wypadku kryzysu 2008 r. i - bardziej szczegółowo - jakie były ich następstwa (zwłaszcza w sektorze bankowym i na rynku finansowym). Na tym tle konieczne jest również dokonanie krótkiej charakterystyki najważniejszych działań podejmowanych przez władze koreańskie po kryzysie azjatyckim. Należy podkreślić, że omawiany problem jest bardzo złożony, dlatego zasygnalizowane zostaną jedynie wybrane problemy. Pokazanie szczegółowo skutków analizowanych kryzysów dla sfery realnej czy działań władz koreańskich w warunkach kryzysu 2008-2009 przekracza ramy niniejszego opracowania.

W toku badań zastosowano analizę porównawczo-opisową oraz krytyczną analizę rozwiązań systemowych. W artykule wykorzystano przede wszystkim zagraniczną literaturę przedmiotu.

* Uniwersytet Ekonomiczny w Katowicach, Wydział Finansów i Ubezpieczeń. 


\section{Warunki rozwoju kryzysu finansowego w 1997 r.}

Kryzys finansowy, który pojawił się w Korei w 1997 r. miał wiele przyczyn, jednak podkreślenia wymaga fakt, że wystąpił on w warunkach liberalizowania przepływów kapitału, co spowodowało ujawnienie wszystkich słabych stron: instytucji finansowych, rynków finansowych, polityki rządu i banku centralnego, a także przedsiębiorstw. Intensywny proces liberalizacji przepływów kapitału miał miejsce od początku lat 90. XX w., co doprowadziło do szybkiego napływu kapitału zagranicznego w latach 1994-1996. Jedną z głównych przyczyn napływu kapitału zagranicznego było zniesienie ograniczeń dotyczących zaciągania kredytów zagranicznych. Rezultatem tego był istotny wzrost zagranicznego zadłużenia krótkoterminowego instytucji finansowych, które z kolei przeznaczały pozyskane środki na kredyty dla sektora przedsiębiorstw ${ }^{1}$. Trzeba nadmienić, że sektor bankowy, podobnie jak cały system finansowy w Korei, funkcjonował w warunkach silnego interwencjonizmu państwowego. Władze miały wpływ na działalność kredytową banków (alokacja kredytu nie była w zasadzie oparta na rachunku ekonomicznym, ale na decyzjach politycznych), na zarządzanie instytucjami finansowymi oraz na wysokość stóp procentowych. Ponadto nadzór finansowy nie działał należycie. Można zaryzykować twierdzenie, iż w Korei nadzór bankowy został niejako zastąpiony poprzez praktycznie nieograniczoną dostępność wsparcia finansowego ze strony władz. Powszechna dostępność pomocy finansowej w sytuacji problemów z płynnością powodowała, że banki nie przestrzegały rygorystycznie standardów bezpieczeństwa². Władze dopuszczały możliwość zawieszania poszczególnych przepisów ostrożnościowych, co powodowało, że koreańskie banki nie stosowały się do regulacji, licząc na ich zmianę w przeszłości ${ }^{3}$. Zarówno bank centralny, jak i Ministerstwo Finansów nie były skłonne do identyfikowania realnych zagrożeń w funkcjonowaniu banków. W takich warunkach banki koreańskie były skłonne do udzielania kredytów bez względu na skalę ryzyka kredytowego. Duże różnice między krajowym i międzynarodowym poziomem stóp procentowych, w warunkach swobody przepływu kapitału powodowały, że banki (jak również inne instytucje pośrednictwa finansowego) miały dostęp do taniego finansowania za granicą. Miało ono w większości charakter krótkoterminowy, a uzyskane w ten sposób środki finansowe banki

1 B. Liberska, Sektor bankowy a kryzys azjatycki, „Bank i Kredyt” 1999, nr 51, dodatek „Bankowe ABC", s. 5.

2 J.Ch. Yoon, The Political Economy of The Financial Liberalization and Crisis in Korea, Graduate School of International Studies, Sogang University, Working Paper, October 1999, No. 99-06, s. 3.

3 M. Ćwikiewicz, Nieefektywność zarządzania na poziomie mikro jako przyczyna kryzysu walutowego (na przykładzie Korei Południowej), „Materiały i Studia” 2000, nr 111, NBP, s. 46-47. 
przeznaczały na udzielanie kredytów długoterminowych krajowym przedsiębiorstwom, jak również na zakup instrumentów finansowych o podwyższonym ryzyku

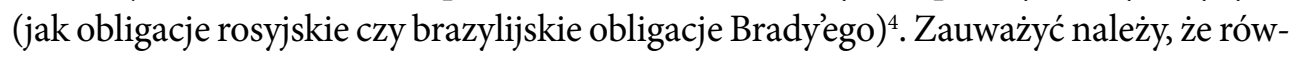
nież przedsiębiorstwa wykorzystywały krótkoterminowe kredyty na długoterminowe inwestycje. Czebole powszechnie finansowały się poprzez krótkoterminowe kredyty, które przeznaczały np. na inwestycje w nieruchomości ${ }^{5}$. Zaciąganiu kredytów zagranicznych przez banki i firmy koreańskie sprzyjało istnienie pochodnych instrumentów kredytowych, które umożliwiały ominięcie niektórych przepisów finansowych. Korzystne warunki dla napływu kapitału, zwłaszcza o charakterze krótkoterminowym, stwarzał również stały kurs walutowy. Cechą charakterystyczną koreańskiego sektora bankowego przed wybuchem kryzysu była ekspansja kredytowa. W latach 1991-1997 średni roczny wzrost kredytów bankowych dla sektora prywatnego wyniósł prawie 18\%, stosunek kredytów bankowych dla sektora prywatnego jako procent PKB przekraczał $50 \%$, a średnia relacja wartości kredytów bankowych do PKB prawie $60 \%{ }^{6}$. Wzrost gospodarczy w Korei finansowany był głównie poprzez kredyt bankowy (wskaźnik „dług do kapitał własny” przekroczył w 1997 r. w wielu koreańskich firmach 500\%), a środki do zwiększania akcji kredytowej pochodziły z zagranicy. Taka sytuacja spowodowała wzrost wrażliwości gospodarki na wstrząsy płynące z zewnątrz, a szczególnie na nagłe zmiany kierunku przepływu kapitału, co miało miejsce w 1997 r. Kryzys finansowy, którego doświadczyła Korea (podobnie jak inne państwa regionu Azji Południowo-Wschodniej) w 1997 r. okazał się być zarówno kryzysem walutowym, jak i bankowym, kryzysem na giełdach papierów wartościowych oraz na rynkach nieruchomości, a w konsekwencji stał się kryzysem ogólnogospodarczym z poważnymi skutkami społecznymi.

\section{Działania post-kryzysowe - restrukturyzacja koreańskiego sektora finansowego}

W obliczu kryzysu Korea dość szybko i zdecydowanie wprowadziła program zalecony przez Międzynarodowy Fundusz Walutowy i rozpoczęła negocjacje z bankami

4 R. Dornbusch, Klucz do sukcesu. Wolne rynki, zdrowy pieniądz i odrobina szczęścia, CeDeWu, Warszawa 2002, s. 105.

5 W strukturze źródeł finansowania 30 największych czeboli w 1996 r. źródła zewnętrzne stanowiły $77,6 \%$, wśród nich dominowały kredyty krótkoterminowe, które stanowiły 63,6\%, a długoterminowe zaledwie 12,7\%. J.Ch. Yoon, op.cit., s. 9.

6 Zob. G. Corsetti, P. Pesenti, N. Roubini, What Caused the Asian Currency and Financial Crisis? Part I: A Macroeconomic View, NBER Working Papers Series, Cambridge 1998. 
komercyjnymi w sprawie rolowania krótkoterminowego zadłużenia. W zamian za wsparcie finansowe ze strony MFW rząd koreański musiał zgodzić się na wprowadzenie kilku prowolnorynkowych reform (lub jak uważa Kang-Kook Lee - pełnego neoliberalizmu w gospodarce ${ }^{7}$ ). Władze zostały zobowiązane do makroekonomicznej stabilizacji poprzez wprowadzenie restrykcyjnej polityki - fiskalnej oraz pieniężnej, które wymagały redukcji wydatków, zwiększenia podatków, odłożenia niepotrzebnych projektów infrastrukturalnych i kontroli wzrostu kredytu w gospodarce, dążenia do opanowania deficytu na rachunku bieżącym i obniżenia inflacji. Korea miała jednak silne podstawy makroekonomiczne, a zaproponowanie polityki wysokich stóp procentowych w warunkach kryzysu spotkało się z zarzutem, że będzie działało to prorecesyjnie, tym bardziej, że słabość przedsiębiorstw i sektora bankowego ograniczała zakres podwyższania stóp procentowych ${ }^{8}$. Już w połowie $1998 \mathrm{r}$. rząd koreański zarzucił restrykcyjną politykę pieniężną i wprowadził bardziej „keynesowskie podejście” - zwiększając istotnie wydatki na cele publiczne9 . Reformy dotyczyły głównie sektora przedsiębiorstw, rynku pracy oraz rynków i instytucji finansowych. Na podstawie porozumienia z MFW władze koreańskie zostały zobowiązane do zredukowania ograniczeń w możliwości posiadania przez cudzoziemców krajowych przedsiębiorstw, otwarcia rynku obligacji dla inwestorów zagranicznych i wprowadzenia większej elastyczności na rynku pracy ${ }^{10}$. Najdalej idąca restrukturyzacja dotyczyła sektora instytucji finansowych: zamknięcia niewypłacalnych podmiotów, ograniczenia problemu złych kredytów i dokapitalizowania banków oraz wprowadzenia bardziej restrykcyjnych regulacji ostrożnościowych. Do końca 2001 r. zlikwidowano 550 z 2072 instytucji finansowych. Rząd wspierał proces fuzji w sektorze finansowym i starał się zachęcić kapitał zagraniczny do inwestowania w krajowe instytucje finansowe (poprzez prywatyzację banków), aby stworzyć instytucje większe i mogące konkurować na światowym rynku finansowym. Do 2008 r. przestało funkcjonować $44 \%$ instytucji finansowych, w tym 16 z 33 banków komercyjnych, 29 z 30 banków handlowych i 15 z 36 przedsiębiorstw zajmujących się obrotem papierami wartościowymi. Restrukturyzacja sektora finansowego wymagała wsparcia finansowego ze strony władz - od końca 1997 r. do początku 2008 r. wydano na ten cel 168,5 bln KRW (ponad 150 mld USD) ${ }^{11}$. Środki na wykup kredytów zagrożonych pozyskiwano z emisji obligacji skarbowych.

\footnotetext{
7 L. Kang-Kook, The Post-Crisis Changes in the Financial System in Korea: Problems of Neoliberal Restructuring and Financial Opening After 1997, Third Word Network, Penang 2010, s. 10.

8 B.B. Aghevli, The Asian Crisis. Causes and Remedies, „Finance and Development” 1999, Vol. 36, No. 2, s. 3 .

9 Kang-Kook L, op.cit. s. 10.

${ }^{10}$ Economic Crisis, „Issues and Controversies on File” 1998, March 20, s. 10-11.

${ }^{11}$ N.J. Bang, From The 1997-98 Asian Financial Crisis to the 2008-09 Global Economic Crisis: Lessons from Korea's Experience, "East Asia Law Review" 2010, Vol. 5(103), s. 19.
} 
Problem kredytów zagrożonych miały również pomóc rozwiązać nowo powołane instytucje - KAMCO (Korea Asset Management Corporation) - Koreańska Korporacja Zarządzania Aktywami - rządowa agencja stworzona w celu nabywania złych aktywów od instytucji finansowych i ich ewentualnego zbywania po restrukturyzacji oraz KDIC (Korea Deposit Insurance Corporation) - Koreańska Korporacja Ubezpieczeń Depozytów - zajmująca się gwarantowaniem środków zgromadzonych w krajowych instytucjach finansowych oraz postępowaniem naprawczo-likwidacyjnym w sytuacji utraty płynności przez instytucję finansową ${ }^{12}$.

W obszarze regulacji ostrożnościowych wprowadzono obowiązek stosowania bazylejskich wymogów kapitałowych - początkowo ustalając współczynnik wypłacalności dla instytucji finansowych na poziomie powyżej 8\%, a następnie powyżej $10 \%$. Od 2000 r. władze wprowadziły nowe kryteria klasyfikacji kredytów zagrożonych. Powyższe decyzje doprowadziły do ograniczenia podaży kredytów w sektorze bankowym. Należy w tym miejscu wspomnieć o wprowadzeniu przez koreański bank centralny instrumentów ostrożnościowych (wprowadzenie limitów wartości współczynników LTV i DTI), które miały ograniczać rozwijający się od końca lat 90 . boom kredytowy na rynku nieruchomości ${ }^{13}$. Istotne zmiany zaszły również w obszarze nadzoru finansowego - wprowadzono model nadzoru zintegrowanego i w 1999 r. powołano Financial Supervisory Commission (Komisję Nadzoru Finansowego), która nie tylko miała być odpowiedzialna za regulację i nadzór finansowy, ale miała aktywnie wspierać proces restrukturyzacji krajowego sektora finansowego ${ }^{14}$.

Gospodarka koreańska szybciej niż się spodziewano wróciła na ścieżkę wzrostu (w 1999 r. PKB Korei zwiększył się o 9,5\%). Wynikało to zarówno z podjętych reform, jak i sprzyjających uwarunkowań zewnętrznych. Innymi pozytywnymi cechami koreańskiej gospodarki na początku XXI w., zwiększającymi zaufanie zagranicznych inwestorów, były: rosnąca nadwyżka w bilansie handlowym, a co za tym idzie zwiększające się rezerwy walutowe (do 262,1 mld USD na koniec 2007 r. $^{15}$ ), stabilizacja kursu waluty koreańskiej do dolara amerykańskiego oraz poprawa sytuacji na krajowej giełdzie papierów wartościowych. Wszystko wskazywało więc na to, że intensywne procesy restrukturyzacji w koreańskim sektorze przedsiębiorstw i systemie

12 M. Rumiński, Kryzys walutowy 1997 roku a restrukturyzacja sektora finansowego i sektora przedsiębiorstw w Korei Południowej, „Materiały i Studia” 2004, nr 174, NBP, s. 1, 28.

${ }_{13}$ Zob. M. Czaplicki, Wykorzystanie polityki makroostrożnościowej w gospodarce wschodzącej na przykładzie Korei Południowej. Wnioski dla Polski, IX Kongres Ekonomistów Polskich, http://www.pte.pl/kongres/referaty, dostęp 02.02.2015.

${ }_{14}$ M. Rumiński, op.cit., s. 25-26.

${ }^{15}$ Republic of Korea: 2009 Article IV Consultation - Staff Report; Staff Statement; Public Information Notice on the Executive Board Discussion; and Statement by the Executive Director for the Republic of Korea, IMF Country Report, August 2009, No. 09/262, s. 25. 
finansowym oraz silne podstawy makroekonomiczne zapewnią trwały wzrost gospodarczy i stabilność finansową w ciągu najbliższych lat.

\section{Koreański sektor finansowy wobec światowego kryzysu finansowego}

Z pewnością można stwierdzić, że koreańska gospodarka i system finansowy były lepiej przygotowane, aby przeciwstawić się zewnętrznym szokom w obliczu rozwoju światowego kryzysu finansowego niż 10 lat wcześniej w trakcie kryzysu azjatyckiego. Niestety, mimo to kryzys lat 2008-2009 miał dla Korei negatywne następstwa zarówno w sektorze finansowym, jak i sferze realnej.

Wybuch światowego kryzysu finansowego we wrześniu 2008 r. spowodował powstanie poważnych napięć w koreańskim sektorze bankowym. Trzeba w tym miejscu nadmienić, że banki krajowe nie angażowały się w transakcje instrumentami opartymi na amerykańskim rynku kredytów subprime. W przededniu kryzysu pod względem wielkości aktywów koreański sektor zajmował trzecie miejsce na kontynencie azjatyckim ( 1485 mld USD - czerwiec 2007 r.).

Analiza depozytów bankowych w warunkach kryzysu wskazuje zarówno na wzrost depozytów terminowych ${ }^{16}$, jak i depozytów na żądanie ${ }^{17}$ oraz rachunków oszczędnościowych z natychmiastowym dostępem ${ }^{18}$. Główną przyczyną tego zjawiska były: skłonność uczestników rynku do poszukiwania bezpiecznych lokat kapitału w warunkach zaburzeń na światowych rynkach finansowych oraz starania podjęte przez banki w celu zwiększenia płynności. Wzrostowi depozytów sprzyjało ich wysokie oprocentowanie - w październiku średnie oprocentowanie depozytów bankowych wzrosło o 26 p.p. O ile światowy kryzys finansowy nie miał negatywnego wpływu na tempo wzrostu depozytów bankowych, o tyle negatywne tendencje można było zauważyć w wypadku akcji kredytowej ${ }^{19}$. Wielkość kredytów obniżyła się zarówno dla finansowania dużych przedsiębiorstw, jak i sektora SME, i to mimo zwiększonego popytu na finansowanie bankowe na skutek trudnej sytuacji na rynku kapitałowym. Banki jednak znacząco ograniczyły dostępność kredytów poprzez zaostrzenie

\footnotetext{
16 Z 10,6 bln KRW w III kwartale 2008 r. do 19,9 bln KRW w ostatnim kwartale 2009 r.

17 Wzrost o 2,7 bln KRW w w analizowanym okresie.

18 Wzrost o 3 bln KRW w analizowanym okresie. Zob. Monetary Policy Report, The Bank of Korea, March 2009, s. 20.

${ }^{19} \mathrm{~W}$ wypadku kredytów dla przedsiębiorstw wielkość udzielonych kredytów była w IV kwartale $2008 \mathrm{r}$. o 13,2 bln KRW niższa niż w poprzednim kwartale.
} 
wymogów kredytowych w warunkach niepewności wywołanej światowym kryzysem, co doprowadziło do znacznych trudności finansowych w sektorze przedsiębiorstw, zwłaszcza MSP. Sytuacja uległa poprawie na początku 2009r. w wyniku działań podjętych przez rząd koreański ${ }^{20}$. W wypadku dużych przedsiębiorstw zahamowanie akcji kredytowej spowodowane było głównie poszukiwaniem przez nie finansowania na rynku instrumentów dłużnych. Należy w tym miejscu nadmienić, że dla gospodarstw domowych zauważalną tendencją jeszcze przed wybuchem kryzysu w 2008 r. było finansowanie się w niebankowych instytucjach finansowych (rozwój tego typu instytucji wspierany był przez władze koreańskie już na długo przed kryzysem azjatyckim).

Negatywną tendencją w koreańskim sektorze bankowym był wzrost kredytów zagrożonych - ich udział w kredytach ogółem wzrósł z 0,7\% w 2007 r. do 1,6\% w czerwcu 2009 r. W latach 2008-2009 zyski po opodatkowaniu oraz wskaźniki ROE i ROA banków pozostawały na stosunkowo niskim (z uwagi na odpisy na rezerwy), jednak dodatnim, poziomie. Wsparcie środkami publicznymi koreańskich banków, wysiłki samych banków mające na celu zwiększenie bazy kapitałowej, osłabienie akcji kredytowej oraz zmiany regulacyjne skutkowały wzrostem wskaźnika adekwatności kapitałowej z 12,8\% w 2008 r. do $14,6 \%$ pod koniec 2009 r.

Bardzo poważnym problemem sektora bankowego w Korei, narastającym jeszcze przed wybuchem światowego kryzysu finansowego w 2008 r., był wzrost zagranicznego zadłużenia krótkoterminowego ${ }^{21}$. Sytuacja była zatem podobna do warunków przed wybuchem kryzysu w 1997 r., a koreański sektor bankowy pozostał, mimo doświadczeń kryzysu azjatyckiego - silnie uzależniony od zagranicznego finansowania. Głównym powodem tego wzrostu było zawieranie kontraktów terminowych w celu zabezpieczenia się przed ryzykiem walutowym. Oczekiwania aprecjacji wona skutkowały wzrostem popytu na instrumenty zabezpieczające przed dalszym umacnianiem się waluty krajowej. Zainteresowane hedgingiem były zwłaszcza duże koreańskie przedsiębiorstwa (np. stocznie), jak również spółki zarządzające aktywami, zwiększające inwestycje na zagranicznych rynkach finansowych. Podmioty te sprzedawały USD $\mathrm{w}$ kontraktach terminowych zawieranych $\mathrm{z}$ bankami, ograniczając straty wynikające $\mathrm{z}$ aprecjacji waluty krajowej ${ }^{22}$. Banki jako podmioty kupujące USD w kontraktach terminowych musiały zrównoważyć otwarte pozycje walutowe poprzez sprzedaż dolarów

\footnotetext{
20 Polegających m.in. na zaleceniu bankom rolowania kredytów dla MSP (z wyjątkiem kredytów już zaległych) oraz rozszerzenie państwowych gwarancji kredytowych.

${ }_{21}$ Wskaźnik zagranicznego zadłużenia krótkoterminowego do rezerw walutowych wzrósł z 30\% w 2005 do prawie $79,1 \%$ w III kwartale $2008 \mathrm{r}$.

22 Sprzedaż netto waluty w kontraktach forward przez koreańskie podmioty wzrosła z 29,2 mld USD w 2005 r. do 71,8 mld USD w 2007 r.
} 
na rynku natychmiastowym. W tym celu pożyczały dolary za granicą, głównie wykorzystując swapy walutowe zawierane z oddziałami banków zagranicznych. Dodatkowo banki zagraniczne wykorzystywały strategię carry trade - zarabiając na różnicy w oprocentowaniu walut - pożyczając środki po niższej stopie dolarowej bądź jenowej i lokując środki po wyższej stopie procentowej na rynku koreańskim. Sytuacja taka powodowała wzrost popytu na wona, a co za tym idzie - jego dalszą aprecjację. Prowadziło to również do wzrostu zagranicznego zadłużenia banków koreańskich - z 51,3 mld USD w 2005 r. do 146 mld USD w II kwartale 2008 r. Całkowite zagraniczne zadłużenie krótkoterminowe wynosiło odpowiednio 65,9 mld USD i 176,2 mld USD - a zatem zadłużenie to wzrastało głównie poprzez sektor bankowy ${ }^{23}$. W przeciwieństwie do następstw kryzysu azjatyckiego w czasie światowego kryzysu finansowego lat 2008-2009 w Korei nie doszło do upadłości większych instytucji.

Rynek pieniężny w Korei pozostał raczej odporny na negatywne następstwa kryzysu w światowym systemie finansowym, chociaż dały się zauważyć problemy wynikające z ograniczonej płynności instytucji finansowych. W warunkach kryzysu lat 2008-2009 zwiększeniu uległo ryzyko kredytowe instytucji finansowych i te z nich z niższymi ratingami kredytowymi odnotowały problemy z pożyczkami na rynku natychmiastowym. Światowy kryzys finansowy oddziałał szczególnie negatywnie na koreański rynek walutowy. Należy podkreślić, że pomimo zmian, którym podlegał krajowy system finansowy po kryzysie 1997 r., rynek ten pozostał niestety rynkiem małym i płytkim, z ograniczoną liczbą uczestników ${ }^{24}$. Dzienne obroty na tym rynku wynosiły mniej niż 1,9\% PKB, z prawie $98 \%$ udziałem USD w transakcjach walutowych ${ }^{25}$. Powyższe uwarunkowania sprzyjały rozwojowi niekorzystnej sytuacji, na skutek pogarszania się warunków w światowym systemie finansowym ${ }^{26}$. Koreańska waluta zaczęła osłabiać się jednak już przed wybuchem światowego kryzysu - w kwietniu 2008 r. Na początku lipca won był jedną z najsłabszych azjatyckich walut, tracąc od początku roku ok. 10\% swojej wartości w stosunku do słabnącego USD oraz ok. 25\% w stosunku do JPY (od czerwca 2007 r.). Spadek wartości koreańskiej waluty był następstwem spowalniającej gospodarki oraz rosnącej inflacji. Władze koreańskie dokonywały kolejnych interwencji, wykorzystując rezerwy walutowe, aby przeciwdziałać narastającej presji na narodową walutę; rynek jednak wydawał

${ }^{23}$ Ch. Hyekyung, Korea's experience with global financial crisis. In: How to prevent the next crisis: Lessons from the country experiences of the global financial crisis, red. A. Bhushan, The North-South Institute, Ottawa 2012, s. 8.

${ }^{24}$ Koreański rynek walutowy funkcjonuje w warunkach płynnego kursu walutowego. Upłynnienie kursu wona nastąpiło w $1997 \mathrm{r}$. w następstwie kryzysu walutowego.

25 Y.A. Choong, South Korea: Wary of Another Financial Crisis, „Global Asia” 2008, Vol. 3, No. 4, s. 41.

${ }^{26}$ Ch.P. Yung, S. Chi-Young, Prospects for Monetary Cooperation in East Asia, Asian Development Bank Institute, ADBI Working Paper Series, October 2011, No. 314, s. 7. 
się coraz bardziej odporny na takie działania ${ }^{27}$. Niestety, sytuacja na rynku walutowym pogorszyła się wraz z narastaniem napięć na światowych rynkach finansowych od września 2008 r. $^{28}$. Waluta koreańska stała się, podobnie jak w 1997 r., celem ataku spekulacyjnego. Ucieczka inwestorów zagranicznych (w tym również funduszy hedgingowych) usiłujących poprawić swoją płynność w dolarach, spowodowała załamanie niewielkiego koreańskiego rynku walutowego ${ }^{29}$. Rynek walutowy znalazł się na skraju kryzysu - waluta krajowa utraciła $45 \%$ wartości w okresie lipiec-listopad 2008 r., a w samym październiku $-22 \%{ }^{30}$. Bank Korei w celu przeciwdziałania atakowi spekulacyjnemu zaczął zwiększać rezerwy walutowe poprzez zagraniczne pożyczki i swapy walutowe zawierane ze Stanami Zjednoczonymi, Chinami oraz Japonią ${ }^{31}$. Niestety, w marcu 2009 r. kurs wona znowu uległ silnemu osłabieniu do 1573 KRW/USD. Dopiero polepszenie warunków w koreańskiej i światowej gospodarce, co poprawiło nastroje inwestorów, spowodowało umacnianie się krajowej waluty w kolejnych miesiącach $2009 \mathrm{r}^{32}$.

Światowy kryzys finansowy nie pozostał bez wpływu na koreański rynek kapitałowy. Na pierwotnym rynku kapitałowym światowy kryzys finansowy spowodował dramatyczny spadek nowych emisji akcji ${ }^{33}$. Na rynku wtórnym odnotowano natomiast silny spadek cen akcji. 16 października 2008 r. południowokoreański indeks giełdowy KOSPI obniżył się o 126,5 punktów i był to największy w historii dzienny spadek cen na krajowej giełdzie. Wpływ na sytuację na giełdzie miały przede wszystkim: pogłębiający się kryzys kredytowy, zagrożenie spowolnieniem w krajowej gospodarce, pogorszenie warunków w gospodarce państw z grupy rynków wschodzących, deprecjacja wona oraz obniżenie zysków koreańskich przedsiębiorstw ${ }^{34}$. Należy jednak w tym miejscu podkreślić, że szczególnie silne oddziaływanie na pogorszenie

27 A. Prusik, Koreę czeka masowa interwencja walutowa?, Portal Spraw Zagranicznych, 9.07.2008, http:// www.psz.pl, dostęp 4.01.2015.

28 Do presji na deprecjację waluty koreańskiej przyczyniło pojawienie się po raz pierwszy od 1998 r. deficytu na rachunku bieżącym bilansu płatniczego.

${ }^{29}$ Kurs wona uległ osłabieniu z 1187 KRW/USD na początku października do 1467,8 KRW/USD 28 października i $1513 \mathrm{KRW} /$ USD 24 listopada.

${ }^{30}$ P.Ch. Yung, S. Chi-Young, op.cit., s. 7.

31 Ponadto, w październiku $2008 \mathrm{r}$. w celu przywrócenia zaufania inwestorów do koreańskiego systemu finansowego i gospodarki, rząd koreański udzielił państwowych gwarancji (do 100 mld USD) na nowe zagraniczne pożyczki z terminem wymagalności przed czerwcem 2009 r. Podobne gwarancje były udzielane w okresie kryzysu azjatyckiego i podobnie jak wówczas nie przyczyniły się przywrócenia zaufania rynków.

32 Ibidem, s. 10-11; K. Kyungsoo, Global Financial Crisis and the Korean Economy, w: Asia And The Global Financial Crisis, red. R. Glick, M.M. Spiegel, Asia Economic Policy Conference Sponsored by the Federal Reserve Bank of San Francisco, Santa Barbara, California, October 19-20, 2009, s. 278.

33 Po rekordowym roku 2007 r., kiedy wielkość emisji osiągnęła 16,6 bln KRW - w 2008 r. wyniosła zaledwie niecałe 4,5 bln KRW.

${ }^{34}$ Financial Supervisory Service 2009, Financial Supervisory Service, http://www.fss.or.kr, dostęp 5.12.2014, s. 6 
sytuacji na koreańskim rynku kapitałowym w okresie kryzysu miał duży odpływ kapitału portfelowego. Wśród reform wprowadzonych po kryzysie 1997 r., a zaleconych przez MFW, było całkowite zniesienie barier w dostępie zagranicznych inwestorów do giełdy papierów wartościowych. Spowodowało to znaczny wzrost udziału inwestorów zagranicznych w krajowej giełdzie (do 44\% w 2004 r.). W warunkach zaburzeń na światowych rynkach finansowych, zwiększyło to istotnie wrażliwość koreańskiego rynku na zmienność przepływu krótkoterminowego kapitału zagranicznego.

\section{Podsumowanie}

Do rozwoju kryzysu w 1997 r. w Korei Południowej przyczyniły się liczne słabości strukturalne i instytucjonalne krajowego systemu finansowego oraz gospodarki. Słabość instytucji finansowych, niewystarczająco rozwinięte rynki finansowe i instrumenty finansowe, stały kurs walutowy, duża skala oraz zmienność przepływów kapitału, nieefektywny i niewłaściwy nadzór finansowy, stworzyły specyficzną "mieszankę wybuchową”. W takich warunkach każda najmniejsza „iskra”, jak chociażby nagła zamiana nastrojów inwestorów zagranicznych, musiała wywołać kryzys finansowy. W wypadku kryzysu lat 2008-2009 na sytuację Korei oddziałały przede wszystkim czynniki zewnętrze, związane z rozprzestrzenianiem się kryzysu subprime.

Porównując dwa analizowane kryzysy finansowe, wydaje się, że mają one kilka wspólnych cech - jak np. silny spadek wartości aktywów finansowych czy konsekwencje w gospodarce (stopa realnego wzrostu PKB zmniejszyła się z 4,7\% w 1997 do $-5,7 \%$ w 1998 r. oraz z 5,1 w 2007 r. do 2,2 w 2008 r. ${ }^{35}$ ). W wypadku kryzysu 2008 r. główny wpływ na obniżenie się PKB miał silny spadek popytu eksportowego, a podczas kryzysu 1997 r. było to obniżenie popytu krajowego. Czas trwania ostatniego kryzysu finansowego był krótszy ${ }^{36}$.

Korea stanęła jednak w obliczu światowego kryzysu finansowego - wzmocniona, $\mathrm{w}$ wyniku podjętych reform $\mathrm{w}$ instytucjach finansowych, w zakresie regulacji i nadzoru finansowego oraz restrukturyzacji przedsiębiorstw (w tym czeboli). W warunkach światowego kryzysu finansowego - w przeciwieństwie do kryzysu azjatyckiego - w Korei nie rozwinął się kryzys bankowy. Nie oznacza to jednak, że koreański

${ }^{35}$ N.J. Bang, op.cit., s. 143.

36 Dla przykładu natomiast PKB powrócił do poziomu sprzed kryzysu - odpowiednio w ciągu czterech kwartałów i sześciu kwartałów. Zob. Ch. Dongchul, Responses of the Korean Economy to the Global Crisis: Another Currency Crisis, Paper prepared for the 2010 EWC/KDI Conference on "Global Economic Crisis: Impacts, Transmission, and Recovery" in Honolulu, Hawaii, on August 19-20, s. 5. 
system finansowy jest wolny od pewnych słabości, jak np. uzależnienie sektora bankowego oraz giełdy od zagranicznego kapitału, niewielki i słaby rynek walutowy. Korea nadal, od lat 90. jest krajem „eksportującym” inwestycje bezpośrednie oraz „importującym” kapitał krótkoterminowy.

W warunkach światowego kryzysu władze koreańskie zdały sobie sprawę, że kluczowe dla przyszłości krajowej gospodarki, silnie uzależnionej od eksportu, jest wspieranie intensywnego, a nie ekstensywnego wzrostu gospodarczego, bo tylko taki wzrost może okazać się długotrwały. Co więcej, oprócz rozwoju Korei jako ważnego centrum usług finansowych na wzór USA, ważne jest wspieranie sfery realnej. Pozytywne następstwa takiej strategii są już widoczne, gdyż Korea Południowa na początku 2015 r. stała się najbardziej innowacyjną gospodarką na świecie.

\section{Bibliografia}

Aghevli B.B., The Asian Crisis. Causes and Remedies, "Finance and Development" June 1999, Vol. 36, No. 2.

Bang N.J., From The 1997-98 Asian Financial Crisis to the 2008-09 Global Economic Crisis: Lessons from Korea’s Experience, "East Asia Law Review" 2010, Vol. 5, No. 103.

Choong Y.A., South Korea: Wary of Another Financial Crisis, "Global Asia" 2008, Vol. 3, No. 4.

Corsetti G., Pesenti P., Roubini N., What Caused the Asian Currency and Financial Crisis? Part I: A Macroeconomic View, NBER Working Papers Series, Cambridge December 1998.

Czaplicki M., Wykorzystanie polityki makroostrożnościowej w gospodarce wschodzaccej na przykładzie Korei Południowej. Wnioski dla Polski, IX Kongres Ekonomistów Polskich, http://www.pte.pl/kongres/referaty, dostęp 02.02.2015.

Ćwikiewicz M., Nieefektywność zarzadzania na poziomie mikro jako przyczyna kryzysu walutowego (na przykładzie Korei Południowej), „Materiały i Studia” 2000, nr 111, NBP.

Dongchul Ch., Responses of the Korean Economy to the Global Crisis: Another Currency Crisis, Paper prepared for the 2010 EWC/KDI Conference on "Global Economic Crisis: Impacts, Transmission, and Recovery" in Honolulu, Hawaii, on August 19-20.

Dornbusch R., Klucz do sukcesu. Wolne rynki, zdrowy pieniądz i odrobina szczęścia, CeDeWu, Warszawa 2002.

Economic Crisis, "Issues and Controversies on File" 1998, March 20.

Financial Supervisory Service 2009, Financial Supervisory Service, http://www.fss.or.kr, dostęp 05.12.2014.

Hyekyung Ch., Korea's experience with global financial crisis. In: How to prevent the next crisis: Lessons from the country experiences of the global financial crisis, ed. A. Bhushan, The North-South Institute, Ottawa 2012. 
Kang-Kook L., The Post-Crisis Changes in the Financial System in Korea: Problems of Neoliberal Restructuring and Financial Opening After 1997, Third Word Network, Penang 2010.

Kyungsoo K., Global Financial Crisis and the Korean Economy, w: Asia And The Global Financial Crisis, red. R. Glick, M.M. Spiegel, Asia Economic Policy Conference Sponsored by the Federal Reserve Bank of San Francisco, Santa Barbara, California, October 19-20, 2009.

Liberska B., Sektor bankowy a kryzys azjatycki, „Bank i Kredyt” 1999, nr 51, dodatek „Bankowe ABC".

Monetary Policy Report, The Bank of Korea, March 2009.

Prusik A., Koree czeka masowa interwencja walutowa? Portal Spraw Zagranicznych, 9.07.2008, http://www.psz.pl, dostęp 4.01.2015.

Republic of Korea: 2009 Article IV Consultation - Staff Report; Staff Statement; Public Information Notice on the Executive Board Discussion; and Statement by the Executive Director for the Republic of Korea, IMF Country Report, August 2009, No. 09/262.

Rumiński M., Kryzys walutowy 1997 roku a restrukturyzacja sektora finansowego i sektora przedsiębiorstw w Korei Poludniowej, „Materiały i Studia” 2004, nr 174, NBP.

Yoon J.Ch., The Political Economy of The Financial Liberalization and Crisis in Korea, Graduate School Of International Studies, Sogang University, Working Paper, October 1999, No. 99-06.

Yung Ch.P., Chi-Young S., Prospects for Monetary Cooperation in East Asia, Asian Development Bank Institute, ADBI Working Paper Series, October 2011, No. 314.

\section{South Korean Experiences of Two Financial Crises}

The article analyzes South Korean experiences of the 1997 and 2008-2009 financial crises. The article describes the conditions which led to the 1997 financial crisis and attempts to answer the question whether similar factors have taken place in 2008. It also describes the consequences of the crises, especially for the banking industry and on the financial market. The article also presents a short overview of the most important measures taken by the Korean authorities in face of the Asian crisis. The two analyzed financial crises have some common characteristics, such as a strong decrease in the value of financial assets and the negative consequences in the economy. However, Korea faced the global financial crisis strengthened thanks to the reforms of financial institutions.

Keywords: global financial crisis, Asian crisis 


\section{Les expériences sud-coréennes des deux crises financières}

L'article analyse les expériences sud-coréennes de la crise financière en 1997 et celle en 2008-2009. L'article décrit les conditions qui ont conduit à la crise financière de 1997 et tente de répondre à la question de savoir si des facteurs similaires ont eu lieu à l'occassion de la crise en 2008. Il décrit également les conséquences de la crise, en particulier pour le secteur bancaire et le marché financier. L'article présente également un bref aperçu des mesures les plus importantes prises par les autorités coréennes face à la crise asiatique. Les deux crises financières analysées ont certaines caractéristiques communes, comme la forte diminution de la valeur des actifs financiers et les conséquences négatives pour l'économie. Toutefois, en 2008, la Corée a été renforcée face à la crise financière mondiale grâce aux réformes des institutions financières.

Mots-clés: la crise financière mondiale, la crise asiatique

\section{Южнокорейский опыт двух финансовых кризисов}

В статье анализируется южнокорейский опыт финансовых кризисов 1997 и 2008-2009 гг. Описываются условия, которые привели к финансовому кризису 1997 г., и предпринимается попытка ответить на вопрос, выступали ли схожие условия в 2008 г. Рассматриваются последствия кризисов, особенно, для банковской отрасли и финансового рынка. Представлен краткий обзор наиболее важных мер, предпринятых корейскими властями в отношении азиатского кризиса. У обоих финансовых кризисов наблюдаются некоторые сходства, как сильное уменьшение стоимости финансовых активов и негативные последствия для экономики. Тем не менее, Корея столкнулась с мировым финансовым кризисом, будучи укрепленной благодаря проведенным реформам финансовых институтов.

Ключевые слова: мировой финансовый кризис, кризис в Азии 
